\title{
Transatlantic Quechuañol: Reading Race through Colonial Translations
}

\author{
ALLISON MARGARET BIGELOW
}

ALLISON MARGARET BIGELOW is an assistant professor of colonial Latin American studies in the Department of Spanish, Italian, and Portuguese at the University of Virginia. With fellowships from the American Council of Learned Societies and the Huntington Library in 2017-18, she completed her book manuscript, Cultural Touchstones: Mining, Refining, and the Languages of Empire in the Early Americas (Omohundro Institute of Early American History and Culture for the $\mathrm{U}$ of North Carolina P, forthcoming). Her work on colonial science, Indigenous studies, and gender systems has been published in Anuario de estudios bolivianos, Early American Literature, Early American Studies, Ethnohistory, ISTOR: Revista de historia internacional, and Journal of Extractive Industries and Society.
T RANSLATION, PAUL RICOEUR WRITES, IS THE SEARCH FOR AND creation of equivalence (specifically, "a supposed equivalence") - not identity or sameness but a rough equivalence of meaning that conveys ideas that are expressed in the sounds and syntaxes of one language into something that resonates with speakers of other tongues (22). In the colonial Americas, which had uneven rates of bilingualism and literacy (alphabetic and iconographic), such equivalences were hard to come by. Yet early Americanists have tended to reinforce Antonio de Nebrija's pithy assessment of language's place as the "compañera" ("companion") of empire: "y de tal manera lo siguió, que juntamente començaron, crecieron, y florecieron, y después junta fue la caida de entrambos" ("language followed empire in such a way that together they began, grew, and flourished, and then together was the fall of both"; 1). ${ }^{1}$ What Nebrija argued in 1492 remains the consensus among colonial and postcolonial scholars; as Robert J. C. Young writes in a recent issue of PMLA, language "had to be fabricated so that translation could take place: both were instruments of colonial rule and power" (1208).

But recent work in translation studies makes a compelling case for a different approach to colonial translation-one that puts Indigenous agencies at the center of New World communication and, especially, intentional miscommunication. Work by Susan Bassnett, Anna Brickhouse, Barbara Cassin, and Emily Apter has shifted the field of translation from a field that defines itself with opposed terms like loyalty and betrayal, foreignization and domestication, and wordfor-word and sense-for-sense to one that uses nuanced paradigms to more closely reflect the real work of translation (Bassnett 5-13). Translation is now understood as a task whose practitioners dwell in the interstices of ideas, beliefs, and sounds that move among multiple

(C) 2019 ALLISON MARGARET BIGELOW

PMLA 134.2 (2019), published by the Modern Language Association of America 
languages, cultures, and ways of knowingliving "on borders and in margins," as Gloria Anzaldúa puts it (19). Instead of defining translations as successes or failures, we now embrace the analytic possibilities of "untranslatables" (Cassin et al.) and "motivated mistranslations" (Brickhouse 19). My research on the colonial scientific archive builds from this expanded definition and in particular from Brickhouse's work on mistranslation as "evidence of a vast Indigenous history of knowledge production and transmission" (47). Brickhouse reads between the lines of things said and unsaid to understand how Indigenous interpreters strategically shared, withheld, and distorted political and geographic information to direct colonial movements and decisions, such as Cristóbal Colón's curious course through the Caribbean: west, west, southeast, west-southwest, and southeast again between 15 October and 5 November 1492 (Brickhouse 17-25; Colón 63-87).

Scientific mistranslations require a slightly different approach. Instead of deciphering Indigenous agencies from the routes described by men like Colón, I compare two stages of scientific translations-first from Quechua into Spanish, which results in a hybrid technical language that we might call Quechuañol, and then from Quechuañol into English, German, and French. (Quechuañol describes a kind of diglossia that is also called "Andean Spanish." Scholars working in the United States use Nahuañol and Quechuañol to describe the hybrid languages of colonial Mexico and the Andes because our audiences recognize them as being similar to Spanglish. ${ }^{3}$ ) This critical genealogy of mistranslation shows when Spanish-speaking miners incorporate Quechua vocabularies into their work and how the scientific discourse of Quechuañol is translated out of European editions. Translators in London, Frankfurt, and Paris replaced racialized colonial vocabularies of "castas de metales" ("metallic castes") and "metales mulatos" ("mulatto metals"), phrases coined by Spanish speakers who mistranslated Andean classifications of matter, with other terms of mineral classification, such that the European volumes impart their own ideas about colors and categories. This method of examining mistranslation allows us to recover Indigenous technical literacies and shed light on other aspects of colonial ideologies-including classifications of race and color.

Vernacular scientific writing, emerging from diverse technical and mechanical arts that range from medicine to metallurgy, is a rich site for documenting Indigenous knowledges and colonial social codes. In the early modern Iberian world, vernacular scientific texts were based on local knowledges that were transmitted throughout an empire that spanned the Atlantic and Pacific oceans. (From 1580 to 1640, Spain and Portugal shared a crown.) Like learned sciences, vernacular technologies were shaped by complex interactions of traditions inherited from antiquity and new knowledges produced in response to local conditions, ranging from political and legal structures to techniques of collecting and classifying herbal and botanical samples (Shapin; Smith). Unlike the learned sciences of cartography, navigation, and astronomy, whose secrets were closely guarded by government officials, vernacular sciences were sites of alphabetic, oral, and visual knowledge collection and dissemination, making them endeavors of collective inquiry (Portuondo; Bleichmar). The crown required that all improvements in the mechanical arts, such as cost savings and production increases, be publicly certified by independent experts, guilds, or official audiences before inventors could be rewarded for their work (Sánchez Gómez et al. 125-54). The law regulating underground discovery was similar. Before miners could be rewarded for finding new sites, they had to run a test vein, search for metals, and stake a claim. Only then could they declare the asset, in speech or writing, to officials who registered the mine, awarded 
rights to the discoverer, and announced the news in public plazas (Molina Martínez). ${ }^{4}$ As such, mining and refining were not only part of public life in Latin America, they were also inclusive industries in terms of gender, ethnicity, and race, as documented in the languages and material cultures that Indigenous, mestizo, and criollo mining experts developed throughout the colonial period (Bigelow, "Women"; Chacón-Torres; Money; Vetter Parodi). ${ }^{5}$

In the larger project from which this essay is drawn, I study a variety of colonial scientific expressions. ${ }^{6}$ Here, I focus on the two-stage mistranslation of metallic colors and categories in Arte de los metales (1640; "The Art of Metals"), a work by the Andalucian priest Álvaro Alonso Barba that incorporated Andean knowledges into Spanish and was translated into English (1670 and 1674), German (1676), and French (1730 and 1751). By examining the relation of naming, color, and classification practices in mining and metallurgical writing, we can better understand how casta categories from the colonial era (the sixteenth and seventeenth centuries) relate to racial systems of the revolutionary and independence eras (the eighteenth and nineteenth centuries).

Barba classifies a number of white, black, and red metals and stones as "castas," regardless of the color of the material. For example, the Chumpi stone, "de color pardo" ("gray black"), is "piedra de casta de Esmeril" ("a rock from the Emery caste"; 12); dull-red, copper-bearing ores, cochizos, are "almost" in the same "casta" as iron hematite ("casi desta casta"; 31). Barba uses many terms in addition to "castas" $(14,31,39 \mathrm{v}, 45 \mathrm{v})$ to categorize metals, sometimes in the same sentence. He employs classifications such as "suerte" ("sort"; 16v, 39v-40), "género" ("genre" or "genus"; 10v, 14), and "especie" ("species," understood in the pre-Linnaean sense of an outward revelation of form; 10v, 20, 35v) to group metals that he calls "paco" ("red," derived from the Quechuan word ppaqu), "mulato" ("mulatto"), and "negrillo" ("little black one"). Color influenced but did not exclusively determine a metal's "casta"; miners used texture, shine, smell, and color to identify minerals in subterranean spaces. Citing evidence of the broad array of sensory input that informed underground classification, Barba notes that mines with "pacos" emitted a "pacible olor" ("peaceable scent") when the ores were not mixed with other metals, such as "mulatos" or "negrillos" (2).

The logic behind Barba's metallic "castas" is illustrative of other kinds of categories in the colonial period. As anthropologists, art historians, and historians like Douglas R. Cope, Ilona Katzew, Laura Lewis, María Elena Martínez, and Matthew Restall demonstrate, color played an important role in the casta categories that figured as prominent social constructions in early modern Iberian life. For example, a woman's physical appearance, including her skin color and hair type, might provide a starting point for her being called castiza ("quadroon"), india (“Indian"), loba (“Afro-Indian"), mestiza ("Spanish-Indian"), mulata ("mulatta"), or negra ("black"). She could negotiate a different identification by using her command of Spanish or her clothing, craft, place of birth, and religion; these last two could be supported by documents that proved her limpieza de sangre, or bloodline free of Jewish or Muslim ancestry, and her reception of sacraments like baptism and marriage. There were also less-tangible factors to consider, such as honor, "calidad" ("quality"), and reputation (Cope 53-56; Martínez 143-46). For people of African descent at the bottom of the social hierarchy, it was possible, but much more difficult, to negotiate a different casta status. By the eighteenth century, attitudes about the inferiority of black and Indigenous peoples were firmly entrenched in colonial law and social life; these beliefs were made visible in paintings that came to "place more emphasis on stratification" than on the "colonial self- 
pride" that seventeenth-century works had emphasized (Katzew 2; see 42-53).

On paper and in portraits, the sistema de castas functioned as a cohesive ideological and legal formula that prioritized whiteness and European ancestry; a straightforward relation between science and society arose as natural philosophical principles from antiquity were rehabilitated into colonial law and society. But in practice, individuals negotiated their statuses based on what was convenient for them at the time-sometimes buying a license to "whiten" and sometimes claiming mestizo identity to avoid paying tribute to the crown (56). In some regions, such as Nueva Granada (now Colombia), the term casta was hardly used at all, while in other places, like Mexico, local definitions of castas differed from the crown's official classifications (Rappaport 7; Katzew 40). The localized meaning of an individual's casta classification in those places within the global reach of the Spanish empire was always nuanced, contingent, and relational rather than fixed or absolute.

The same was true of the entire sistema de castas as it changed over time and expanded into new geographies. Based on medieval Iberian doctrines of limpieza de sangre, which were concerned with documenting and regulating non-Christian ancestry rather than phonotypical traits, the sistema de castas found its way, by means of colonial Latin American interpretations of Spanish law, into the public policies of independent republics in which racial classifications served "to exclude from power individuals western science construed as essentially different due to blood, ancestry, or color" (Lewis 4). If the relation of race and modern science became clearer by the nineteenth century, as scientific inquiry, experimentation, question framing, and modes of specimen collecting helped justify racial domination and prejudice, the colonial context was more ambiguous (Hammonds and Herzig xi-xiv). As Restall concludes, "Although modern ideas about race were forming toward the end of the colonial period, and Spanish American thinkers may have contributed to that formation, the fullfledged ideologies of race and racism that came to underpin imperialism and slavery in the nineteenth century cannot be projected back onto Spanish America in the sixteenth through eighteenth centuries" (81). We need a broader understanding of how racial ideologies and scientific vocabularies developed in those formative centuries of colonial life.

Throughout the sixteenth and seventeenth centuries, gender played an important role in determining casta classifications. Paternal and maternal lineage had different social and legal consequences. According to Spanish law, the children of negros were born free, while those born to negras were enslaved (Restall 79). Early modern ideas about gender gave greater import to the father's line, because traits passed through the mother were considered weak. These ideas came from the natural philosophical traditions of antiquity, in which masculine properties were said to give shape to form, while the feminine was form itself (Plato 90e-91d; Aristotle 192a). Early moderns generally believed that mothers influenced childhood development through the imagination, such that thinking of a strawberry during pregnancy would result in a child with a red birthmark, and by transmitting physical, intellectual, and emotional qualities while breastfeeding (Davidson 20-25). In medieval Spain and throughout the early modern Iberian Atlantic world, breast milk was understood as a type of blood that enabled physical and moral traits to be transmitted across racial and ethnic categories; some seventeenthcentury writers argued that Indigenous wet nurses were responsible for the degeneration of criollo subjects in the Americas (Rappaport 18-20). Others, like the mestizo author El Inca Garcilaso de la Vega (1539-1616), claimed that knowledge communicated through breast milk authorizes them to write New World histories: "Que yo protesto decir llanamente la 
relación que mamé en la leche y la que desde entonces acá he tenido. ... Y no escribiré novedades ..." ("I declare to plainly tell the story that I imbibed with mother's milk and that which I have held here since. ... And I will not write novelties ..."; 50).

Colonial societies bore out natural scientific ideas on form, matter, and generation by "echoing paternalistic religious and government policies that depicted relations among Spaniards, Indigenous people, and blacks in gendered forms" (Martínez 4). Some writers, such as the Jesuit priest José de Acosta (15401600), translated conventional ideas on form and matter into justifications of conquest, reasoning that since metals grew passively underground they required active, human intervention to be converted into wealth and put in the service of the church universal and the empire that did the church's work in the world. God blessed South America with abundant deposits of subterranean matter to ensure that Spaniards would flock to the region, just as "lo que haze vn padre con vna hija fea para casarla, que es darle mucha dote" ("a father who wishes to marry off his ugly daughter will give her a great dowry"; Acosta 197; see Bigelow, "La dote" 149-52).

Other writers were more ambivalent. For Barba, metallic matter is not "a homogenous and passive principle," as Orlando Bentancor writes in his analysis of the priest's theories of minerogenesis, but rather "the carrier of their differential qualities" (121). Barba's theory of metallic generation beneath the surface of the earth, like his principles of mineral sorting above ground, depend on degrees of purity, or what he calls the "pureza" ("purity") and "perfección" ("perfection") of a stone, metal, or mineral's "virtud impressa" ("imprinted virtue"; 19v). There are no absolute differences between metals and semimetals or among metals, plants, and animals; all are animate beings "proporcionadas a lo que mas tarda en su generación la naturaleza" ("proportionate to the length of time for Nature to generate them"; 11v-12). Human beings and animals have hands and feet because their soft, receptive temperaments, "tan vniforme, y bien mezclado" ("so uniform and so wellmixed"; 12), can be impressed upon by nature. In contrast, stones and metals are harder and more resistant to the imprinting of external forms. Only long spans of geological time can cause metallic matter to change form and become more refined. This is why gold and silver, as older metals, are more "purificadas" ("purified") than copper, iron, tin, and lead (21v). Their perfection is signaled, in part, by color. Gold and copper are "amarillo, o rubio" ("yellow-red") because they contain notable quantities of sulfur; but copper "desdize" ("deteriorates") from the color, "nobleza" ("nobility"), and "quilates" ("fineness") of gold because of its "impuridad, y combustion de sus partes, y mala mixtion dellas" ("impurity and combustion of its parts, and their bad mixture"; 21). According to Bentancor, Barba's theory of similarity and difference-his explanation of why precious and base metals share some "temperamental qualities" but have visibly different exteriors-"effectively 'ungrounds' that which metaphysical and ontological colonial thought take for granted and which forms the heart of imperial reason: the division between an active, founding form and a passive, founded matter" (122).

Like these learned theories, vernacular scientific writing-as it developed into hybrid technical literacies in the Americasalso "ungrounds" imperial logic. Miners in the Andes converted Indigenous definitions of writing, such as "quellccani" or "quillcani" ("to write-paint”; González Holguín 301, 274) and "pallani" ("to sort or choose by hand from the earth, trees, or harvest"; Santo Tomás 170), into forms of administrative record keeping. Quechuan nouns were borrowed into Spanish verb paradigms, and terms derived from one area of natural scientific practice, such as agriculture, were repurposed into other knowledge sectors, 
such as mining (Bigelow, "La dote" 152-61). Instead of importing the Quechuan terms as they were, most authors modified words like quellccani or pallani so that they sounded more natural in Spanish: quilcar and pallar. In Quechua, pallar is a noun that means "los frisoles grandes como hauas llanos" ("large beans like fava or field beans"; González Holguín 274). But in Quechuañol, pallar refers to mineral sorting, as when Barba titles a chapter "Del pallar, o escoger los metales" ("Of Pallaring or Choosing Metals”; 40). European translators did not know how to interpret the Quechuañol verb, so they treated it as a synonym of the word they recognized, escoger ("to choose"), and titled their chapters "Of the Sorting of Oar" (Montagu, Art 2.12) and "Bon allerley Arten des Erzes" (Lange 137).

In the Andes, pallar could not be eliminated from the written record; it signified writing itself. When Spanish speakers recorded miners' hauls at the end of each week, they called it "pallar los Indios" ("to writesort the Indians") because the Quechuañol verb pallar was known as a synonym of quilcar. As the overseer García de Llanos explains in his dictionary of mining terms from Potosí, "y así se dice pallar los indios al tomarles cuenta y asentarles lo que han trabajado, lo cual asimismo se dice quilcar" ("and so they say that to 'pallar the Indians' means to take account of them and what they have worked, for which they also say 'quilcar"'; 98). In the translation from spoken Quechua to written Spanish, technical terms for sorting overlapped with vocabularies for novel forms of expression in Quechuañol (pallani and pallar; quellccani and quilcar). ${ }^{7}$ Miners developed these expressions in response to changes in the silver industry, such as discoveries of new kinds of metallic mixtures and technology transfers that brought Mexican methods of amalgamation to the refineries of Alto Peru. ${ }^{8}$

Andeanists call this multilingual blend of oral and written literacies "quilca" (or "quillca" in colonial orthography). The par- ticular kind of "semiotic heterogeneity that characterized the Andes in general" (Brokaw 167) at once conveys information and expresses aesthetic principles across diverse media forms including architecture, ceramics, counting devices, and sculpture, "an entire framework of interrelated objects and practices" (170; see 167-70). Rocío QuispeAgnoli's study of Guaman Poma de Ayala's quilca andina, or visual, alphabetic signifiers, reveals how Andean authors integrated signs from tokapu ("textiles"), khipus ("cords"), and keros ("painted vases") into colonial-era lettered scripts (264-72). Recently, scholars have correlated musical sounds and textile patterns, proposing new ways both to expand the study of the sonic, graphic, and storytelling complexity of Andean literacies and to examine change and continuity over time (see, e.g., Borras). Literary critics have not often studied technical manuals from the Andes. Building from the work of scholars like Joanne Rappaport, Tom Cummins, and Walter Mignolo, I argue that these texts suggest how a new approach to the colonial scientific archive might unsettle and unground some core assumptions about the language of race, the logic of color, and the place of nonalphabetic Indigenous literacies-including technical literacies-in knowledge production throughout the early Americas (Rappaport and Cummins 3-14, 19-25; Mignolo 29-52, 322-25).

While we have often approached the recovery of Indigenous knowledges and the study of colonial racial ideologies as separate processes, this article, supported by Barba's Arte de los metales, insists on their entanglement. The book, based on the priest's experience in mining communities in and around Potosí, in modern-day Bolivia, from the 1590 s to the 1630 s, was first printed in Madrid's Royal Printing House in 1640. In the one-hundred-odd years that followed the original publication, it circulated in at least twenty editions that were issued by private hands, family-run shops, and royal printing 
houses. ${ }^{9}$ It is known to have been printed in five major European languages, including English, French, German, Latin, and Spanish. ${ }^{10}$

In 1763, the Pietist community of Ephrata, Pennsylvania, issued a German translation, the first edition of the book to be published in the Americas. Unlike those of the other German volumes, its subtitle proclaimed to follow the English translation of Edward Montagu, published in 1670, rather than Barba's original text of 1640: "In zwey Büchern, Vormals im Spanischen beschrieben durch Albaro Alonso Barba ... Hernach in das Engländische übersetzt durch Edward, Graff von Dandwich, Anno 1669" ("In Two Books, First Written in Spanish by Alvaro Alonso Barba ... Correctly Translated Hereafter in English by Edward, Earl of Sandwich, in the Year of 1669"; Gründlicher Unterricht). This book, which became part of President George Washington's library (Washington et al. 133), is an example of how technical knowledge of mining and metallurgy moved from the Americas to Europe and back in multiple languages and literary contexts.

Translators in England, Germany, and France were comfortable reconciling competing ideas from antiquity and the medieval era, such as when Barba glossed different views on the location of mineral formation (i.e., where stones and metals were generated). One argument came from the ninthcentury Persian physician Avicenna, who published in Arabic, and another from the eleventh-century German priest Albertus Magnus, who wrote in Latin. Translators did not intervene when Barba presented conflicting scientific ideas of writers whose authority was established in the Old World. ${ }^{11}$

In contrast, the same translators struggled to understand Hispanized forms of Indigenous American languages, such as those used to classify silver ores in Potosí. Like the ancients, Andean miners did not all agree on the scientific and technical aspects of metalwork. Translators in Europe developed a range of strategies to explain these diverse ways of knowing to their readers. According to Barba, miners grouped metals into three categories: "Pacos, Mulatos y Negrillos" (39v). The first group, "que llaman Pacos" ("which they call Pacos"), took its name from the Quechuan word ppaqu ("red"). In coining this new word, Spanish speakers adapted the seventeenth-century Quechuan term for "red" or "bright red" (ppaqu, today expressed as puka or pillku, depending on the region) $)^{12}$ into sounds that they were comfortable with, rendering the metallic body that we now call silver chloride as "Pacos."

As is the case with pallar, which means "to write-paint or to sort" in Quechuañol and "field beans" in Quechua, paco signifies one thing in the hybrid language of mining communities and another thing for monolingual Quechua speakers. Bilingual QuechuaSpanish dictionaries from the colonial era translate the term and its variants as "El hongo llano grande de comer" ("large, edible field mushroom") and "hongo de prado" (“field mushroom”; González Holguín 271); "Orejera, lo que meten los yndios orejones en el hueco de la oreja" ("ritual earring for nobles"; Santo Tomás 66v); "Vayo" and "color buriel" ("yellow-white"; Santo Tomás 158); and "Cosa bermeja rubia roxa" and "bermeja cosa" ("bright red-blonde-yellow"; Santo Tomás 20v). These are not the only examples of the same word meaning different things in Quechua, Spanish, and Quechuañol. Felipe Guaman Poma de Ayala humorously relates Spanish speakers' frustration when they ordered Indigenous people to bring them goods, cursing "anda puto" ("go, damnit"; 304). For this, they would receive copper and squash, because in Quechua "anda" meant "copper" and "puto" meant "squash."

For their parts, translators in Europe were unfamiliar with Barba's Quechuanol, so they converted paco into a term that they knew from the Castilian lexicon, palo ("wood"). Thus, silver chlorides from the 
Andes (pacos) become metals "which they call Palos" (Montagu, Art 1.2), or in German "das sie Palos heißen" (Lange 4). In contrast, all the translations correctly declare that the metal is red: "of a Red colour" (Montagu, Art 2.8), "eine rothe Farbe" (Lange 134), and "veut dire Rouge" (Hautin de Villars 30).

With a term like negrillos ("silver sulfides"), the same translators make different choices. Sometimes they translate the concept behind the name rather than the name itself, such that the phrases "negrillos" and "negrillos de plata" (Barba 10, 10v) become "black Oar" or "black Silver Oar" (Montagu, Art 1.39, 41), and "schwartz Erze" or "schwarzen Silber-Erz" (Lange 32, 33). At other times they leave the name in the source language and do not look for a lexical equivalent, as they do with pacos. They render the metallic category in the same terms but with different typographic presentations: "Negrillos" (Montagu, Art 1.41), "Negrillos" (Lange 33), and "NEGRILLOS" (Hautin de Villars 30).

Much of their confusion stems from the unclear relation between the color properties of the metals and the racialized names of the categories. As Barba explains, "pacos" also include "metales verdes cobriços" ("green copper-bearing ores"). He notes that even though "negrillos," which contain a high amount of copper, are named for their color, "no todos los metales negros se comprehenden debaxo de nombre de negrillos" ("not all black metals are negrillos"; 39v).

The color properties of "mulatos" were even less precise than reddish metals that were also green and the black metals that did not include all black metals. Barba places them at "un medio entre pacos y negrillos" ("the mean between pacos and negrillos"), underscoring their naturally intermediary place: "y asi lo criò la naturaleza entre los dos" ("and so nature reared it between the two"). He defines the color of "metal mulato" in humoral terms, aligning it with the organ whose black bile made people melancholy: "tiene el color baço" ("it is spleen-hued"; 39v). Earlyseventeenth-century dictionaries suggest a range of color terms that are included under this splenetic umbrella. César Oudin's French and Spanish dictionary of 1607 suggests that the Spanish phrase "baco, pardo, cosa vn poco negra" ("spleen, black, thing that is a little black") could be translated into French as "bis, gris, un peur noir, brun, obscur" ("spleen, gray, a little black, brown, dark"; 78). John Minshew's polyglot dictionary of eleven languages, not all of which were included in each entry, offers similar terms for "bazo de color" ("spleen colored"), which he translates into Latin and English: "color inter fuscum \& nigrum" ("a sad gray or a light black"; 39 ).

Given these lexical possibilities, early modern translators had many ways to explain the color properties of "metal mulato" to their readers. They could leave the term in the source language, translate the idea behind the name, or seek cognates in their own tongues. Montagu chose this option for other technical terms. According to the Oxford English Dictionary $(O E D)$, he introduced the word caxon into English from the Spanish cajón, or mixing bin ("Caxon"). Although the translators do not approximate the terms pacos or negrillos, the example of "metales mulatos" is different, because the terms mullatre and mulatto had existed in French and English since 1544 and 1591 ("Mulatto"). The translators do not opt to use cognates for this phrase. Instead, they recognize that there is something about Barba's "metal mulato" that they cannot express in their own languages. Each again elects to use different typographic presentations, but they all leave the name in the source language, not realizing that the idea had already been translated from Indigenous Andean languages. They render the metallic category as "Mulatos" (Montagu, Art 2.9), "Mulatos" (Lange 134), and "MULATOS" (Hautin de Villars 30).

While they agree on what to call the category, they disagree on its color properties. Montagu thinks that the term "mulato" 
refers to the color of the ore, not the name of the metal. He thus writes, "Mulatos is a colour between the Pacos and Negrillos; and in the Mines, Mettal of that colour is produced in the same order." Just as he removes the clarification that nature created "Mulatos" between the underground antipodes of "the Pacos and Negrillos," Montagu also changes the color properties of "Mulatos" from "baço" ("spleen-hued") to "a Brown colour" (Art 2.9). Johann Lange follows Montagu, rendering "Mulatos" as "einer braunen Farbe" ("a brown color") that is located "zwischen Pacos und Negrillos" ("between paco and negrillo metals"), giving no sense of nature's work in the process (135). In contrast, Charles Hautin de Villars preserves the role of nature and declines to fix a color to the category "metales mulatos." Francophone audiences read, "MULATO veut dire, Minéral, qui tient le milieu entre le Paco \& le Negrillo. La Nature l'a créé de la sorte entre ces deus Metaux" ("Mulato means an ore that is a medium between the paco and the negrillo. In this way, nature created it between the two metals"; 31).

The confusion caused by the racialized color terminology of the Spanish colonial source-confusion that is faithfully preserved in Atlantic translations-reflects a mistranslation of natural knowledge from the Andes, where Indigenous miners classified metals by depth, not color. "Pacos" are found closest to the surface, "negrillos" occur at the greatest depths, and "mulatos," what Llanos calls "cenicientos" ("ashy"), occupy a transitional zone of two or three "estados" ("body lengths") between the other metals (85). Andean miners undoubtedly had their own way of organizing space through language, perhaps using terms like pactascak, pactas mitta, or chaupi mitta, all of which meant "a middle place between two points" in seventeenth-century Quechua (González Holguín 584). Spanish speakers seem to have (mis)translated the Andean concept of "a middle place" into their own term for something in the middle: "metal mulato."
None of the color terms in Barba's tripartite system "Pacos, Mulatos y Negrillos" actually align with colors, because silver ores change colors as they are exposed to oxygen and mixed with other elements, such as sulfur, tin, and lead. Rather, the names of the categories represent Spanish mistranslations of Indigenous ways of knowing. In turn, European translators inscribed their texts with different expressions describing the color of "mulatos," such that the ideas that circulated in English and German reading communities differed from those circulating in French and Spanish communities, just as the racialized lexicon of Spanish-speaking miners differed from the spatial logic of Andean classifications.

Although Hautin de Villars is closer to Barba in this passage, his translation bears little formal resemblance to the source text. Barba's Arte de los metales was printed in five books with chapters dividing material within each book. Books 1 and 2, which contain fifty-eight chapters altogether, were the first to be translated in Europe. By contrast, Hautin de Villars's single book contained fortyone chapters that were drawn variously from books 1-5 and arranged in a different order than they were in Barba's work. For example, Hautin de Villars's first chapter, "De la Génération des Metaux" ("On the Generation of Metals,") was from book 1, chapter 18 of the Arte de los metales. Barba's book 2, chapter 3, which explained the classification of "Pacos, Mulatos y Negrillos," became the more prominent chapter 7 in the French volume.

Hautin de Villars's translation was published in 1730; twenty years later, Nicolas Lenglet du Fresnoy completed a Frenchlanguage translation of all five books of Arte de los metales, in the order of the original text. But his work departed significantly from Barba's book and Hautin de Villars's translation. For example, in the passage about " $\mathrm{Pa}$ cos, Mulatos y Negrillos," Lenglet du Fresnoy moves the description of "Pacos" to a footnote, marked by "(I)" after the name of the 
metal, writing "les Mineurs les réduisent à trois espéces générales qu’ils nomment Pacos, Mulatos, \& Negrillos" ("Miners reduce them to three general kinds that are called pacos, mulatos, and negrillos"; 137), but only two of those categories were described in the body of the text. First was mulato: "Ils appellent $\mathrm{Mu}$ lato ce qui tient le milieu entre le Paco (I) \& le Negrillo" ("They call mulato that which is in the middle of the paco (I) and the negrillo"). Like Montagu and Lange, he removes the line about nature; unlike them, he skips the line about "spleen-colored" metals. On matters of color terms and racial vocabularies, Hautin de Villars follows Barba's language more closely than any other translator does, but the structures of the English, German, and later French translations more closely resemble the organization of the source text.

The different versions of Barba's book that circulated among and within English-, French-, German-, and Spanish-language communities underscore the role played by linguistic, formal, and cultural translation in shaping readers' experiences of their texts. Each of these translations-including those from Quechua into Quechuañol-represents a new interpretation of colonial knowledge. Attending to mistranslation is an important method for recovering the voices of Quechuaspeaking miners and for understanding how variations in the translations provide insight into the making of scientific vocabularies, racial lexicons, and literary communities.

In turn, these translations-in moving from Indigenous Andean languages to colonial Spanish and the dominant languages of Europe-may have helped give organizing power to racial categories at a key time in the formation of Western scientific thought. According to Mignolo, in the transition from the Renaissance to the Enlightenment, English, German, and French replaced Spanish, Italian, and Portuguese as the perceived "knowledge-generating" languages of reason and scientific modernity. In Mignolo's com- pelling history of the perception and power of language, there was "a fracture within the Romance languages," and the fault line was French. Although French "maintained the expressive flair attributed to the Romance languages, it was also the language of philosophical rigor and one of the colonial powers of modernity" (ix). After World War II, these divisions were magnified by new geographic interpretations of political economy, in which much of "the Francophone world (with the exception of Canada) began to share with Spanish its belonging to the Third World" (x).

The divergence of French from other Romance languages in the making of modernity throws into sharp relief the uneasy place of Hautin de Villars's translation of 1730, published well before Immanuel Kant offered a two-part taxonomy "[o]n national characters in so far as they rest upon the different feeling of the sublime and the beautiful" (50). Writing in 1764, Kant sketched a model of world division in which France, England, and Germany stood on one side and Spain, Italy, and Portugal on the other; these six European powers formed the analogical root of his comparative framework, wherein " $\mathrm{i}] \mathrm{f}$ the Arabs are as it were the Spaniards of the Orient, then the Persians are the Frenchmen of Asia" and "the Japanese can be regarded as it were as the Englishmen of this part of the world" (58). Such assessments were not just anthropological, aesthetic, or racist; they were, for Kant, evaluations of morality: "The characters of mind of the peoples are most evident in that in them which is moral" (51). ${ }^{13}$

By the nineteenth century, English and German scholars diverged from their peers in France on the relation of color to civilization. Whereas English and German translations of Arte de los metales consistently bound color to racial vocabularies from 1670 to 1767 , albeit in different ways, nineteenth-century scholars and politicians in England and Germany converted color into a way of analyzing human development. Colonial writing 
on color and categorization circulated with global flows of American silver and in transatlantic translations of important technical treatises; the echoes of those translations in nineteenth-century medical thought and public policy in Europe should prompt us to reconsider the work of translation and mistranslation in the diverse scientific archives of the early Americas.

Consider the influence of color classification and translation in nineteenth-century England. Before serving as prime minister of the United Kingdom, William Ewart Gladstone was a prolific classicist. In the introduction to his Studies on Homer and the Homeric Age (1858), Gladstone laments the imprecise color terms of ancient Greek, and he wonders how Homer's works, the model for the Western tradition, could overlook a matter of such importance (Saunders 7). Even while he was involved in politics, Gladstone corresponded about classics. Writing on stationery stamped from Hawarden Castle, Chester, around 1885 , he debated what sources of water supplied "Homer's European sea" (Letter to an unnamed recipient), ${ }^{14}$ and on 30 December 1886 , in a response to T. W. Brown ${ }^{15}$ on circumcision practices in Egypt and Greece, he wondered whether Hermes has agency in Homer, and opined how strange it is that no one "reached indications of the rising up of the Achenian nationality, and its disposition to give tit for tat" (Letter to T. W. Brown). In 1877, he revised his ideas about Homer's color vocabularies slightly, to accord with Charles Darwin's The Descent of Man, and Selection in Relation to Sex (1871), which built from his earlier work, On the Origin of Species by Means of Natural Selection; or, The Preservation of Favoured Races in the Struggle for Life (1859). However, Gladstone's ideas about the superiority of Greek culture and the necessity of classical education in modern Britain remained unchanged (Saunders 10).

In response to Gladstone, the German scholar Lazarus Geiger developed a theory that made the perception of color, rather than color vocabulary, into an index of social progress. He calls it a "Schema des Farbenspectrums" ("schema of color spectrums") that runs from dark (black and red) to light (white and yellow). Advanced societies developed the ability to perceive and name green and blue. The cornerstone of Geiger's spectral reading of human society was thus "der Dualismus von schwarz und roth" ("a duality between black and red"), complemented by additional colors over time (48). ${ }^{16}$ Some two hundred years earlier, Barba had distinguished red-named-but-not-always-red "pacos" and black-named-but-not-always-black "negrillos" in similar terms. But for Barba, this distinction forms foundational technical knowledge, not determinative categories of civilization; he calls the chapter "Del conocimiento de los metales, y las diferencias dellos ay" ("Of the Knowledge of Metals and the Differences among Them"; 39).

For Geiger, the white-black spectrum ("wieß=gelb=roth=schwarzen" ["white=yellow=red=black"]) was a universal truth, because all human societies perceive and express dark colors in contrast to light hues (57). But not all languages have terms for "bläu" ("blue") and "grün" ("green"), so Geiger reasoned that these were the color terms that divide advanced civilizations from primitive ones (58). After Geiger's work was published, his contemporaries took to measuring people's eyes, tongues, and mouths to determine how they perceived color and gave voice to it. On 8 September and 24 November 1879, the prominent medical journal Berliner klinische Wochenschrift: Organ für practische Aerzte published Carl Schroeder's "Die Entwicklung des Farbensinnes am menschlichen Auge" ("The Evolution of the Color Perception of the Human Eye") and Ludwig Kotelmann's "Die Augen von 9 Lappländern, 3 Patagoniern, 13 Nubiern und 1 Neger vom weissen Nil" ("The Eyes of Nine Lapps, Three Patagonians, Thirteen Nubians and One Negro along the White Nile"). 
Scholars in England pushed back on this physiological history of civilization, arguing that Darwin's theories of evolution disproved the conclusions of German philologists. Both parties ultimately agreed that physical body parts were not responsible for primitive underdevelopment and that instead culture was to blame. In England, Grant Allen consulted surveys, gathered in the British Museum, of Indigenous communities in Polynesia and the Americas (Saunders 12). In Germany, Hugh Magnus studied the results of surveys of sixtyone "primitive" peoples from Africa, Asia, Australia, and Europe (specifically Latvia and northern Norway). Magnus also consulted a survey of "the Saramakka Negroes in Guayana" and of several Indigenous communities of North America, including the Odjibwe, Challam, Sioux, Pah, Ute, Cheyenne, Crow, Bannack, Umatilla, Flathead, Nez Percez, Snake, and Makah nations (Magnus 136).

That these researchers gathered data on the physiologies, color perceptions, and vocabularies of people from every region of the world reveals how the political and economic power of nineteenth-century England and Germany-countries with resources to support global modes of collection-allowed their scholars to provide politically expedient conclusions that proved "empirically" how language indexed civilization and barbarity. The legacy of nineteenth-century ideas about color, identity, language, and the kinds of knowledges that are valued in alphabetic writing necessitates revisiting the colonial scientific archive. Many of these ideas took root during the epistemic encounter of the Old World and the New. Readings of race, color, and different ways of knowing were written into colonial scientific literatures, just as Indigenous knowledges were consistently translated out of them.

It is almost always the case that when translators in Western Europe diverge in their readings of a passage from Barba, the key terms can be traced back to a translation from Quechua into Spanish. Their confusion is entirely understandable; colonial practitioners of the art of mining, such as Indigenous miners, colonial overseers, and writers like Barba, worked to amalgamate new kinds of knowledge and to understand multilingual classifications of dynamic metallic matter.

But in the chain of seventeenth-century mistranslations, Montagu, Lange, and Hautin de Villars then conflate Spanish and Quechua. This is less easy to understand, because Barba describes his collaborations with Indigenous miners and explains that Spanish-speaking miners did not devise the names "Pacos, $\mathrm{Mu}$ latos y Negrillos." In the first line of that passage, he writes, "Paco en la lengua general de aquesta tierra quiere decir bermejo" ("Paco in the general language of this land means bright red"; 39v). It is clear that the general language of Potosí is not Spanish, because Barba would not need to explain to Spanish speakers what red means. But European translators treated miners from colonial Latin America as if they all spoke the same "lengua general" ("general language"). ${ }^{17}$ Montagu notes that "the Miners reduce these differences unto three general heads, which the Spaniards call, I. Pacos, 2. Mulatos, and 3. Negrillos. Paco in the general language of this Country is as much as to say of a Red colour" (Art 2.8). Lange likewise assigns the logic of classification to Spaniards and translates "Paco" as "eine rothe Farbe" ("a red color"), also clarifying that "I. Pacos, 2. Mulatos, 3. Negrillos" is what the terms would be called in German (134).

European translators did not look for evidence of Indigenous knowledge, instead translating the source text in a way that obscured the contributions of Andean miners. Their readers thus had no sense that Indigenous perceptions and vocabularies shaped colonial scientific discourse-especially its racialized terms and color vocabularies. Quechua was the source language for Barba's Spanish-language volume, but Spanish became the source for its translations. By replacing Quechuañol with Spanish, translating 
terms of color and classification in different ways, and printing the translations in diverse editions, networks of translators and printers in early modern Europe produced very different reading experiences for their audiences. On one point they all agreed, though: Indigenous miners provided labor, not knowledge.

Precisely because the early modern scientific archive reveals so few equivalences and instead displays a long genealogy of misunderstanding, an attention to mistranslation can help identify the technical literacies of women and men who "wrote without letters" (Mignolo 319). When they mistranslated, seventeenth-century translators were not necessarily unfaithful to their sources; rather, they created culturally legible texts for specific communities of readers-their own (Coldiron). As early modern translation practices began to accommodate new understandings of original authorship, translation became a way of creating and separating communities of readers (Bassnett 11-13). By moving away from the "constant background echo of 'traduttore, traditore' ['translator, traitor']," a foundational metaphor of translation in "the Western tradition," we begin to see how mistranslated texts are evidence of important historical realities, from the incorporation of Indigenous knowledges to the development of racial ideologies (Wyke 34). Readers in England, Germany, France, and the Spanishspeaking world were brought into a community of people who had read Barba, but these readers were also divided from each other because each translator conveyed different ideas about knowledge, race, and color. For modern scholars, mistranslation provides a way to resolve some of the methodological challenges that we face in working with fragmented and asymmetrical colonial archives. Historians of science and technology have long known that Indigenous miners formed the majority of the workforce in the colonial silver industry, but without books written in Quechua, Aimara, or Nahuatl it has been difficult to document ideas and knowledge production in the same way that we chart labor and silver output. My research suggests that mistranslation-concrete, traceable evidence of misunderstandings, silences, and omissions between texts-can document Indigenous intellectual contributions to colonial sciences and identify why and how those contributions were silenced.

The editors of the Dictionary of Untranslatables: A Philosophical Lexicon, recently translated from the French into English by a team that was led by Barbara Cassin, Emily Apter, Jacques Lezra, and Michael Wood, argue convincingly that language is an inherently social medium whose "networks of words and senses" reflect deeply personal ideas, beliefs, and definitions (Cassin et al. xix). This is what George Steiner meant when he suggested nearly forty years ago that the "personal lexicon" of individual speakers and writers "inevitably qualifies the definitions, connotations, semantic moves current in public discourse" (46) and, thus, that translations are intimately personal moments of communal message shaping, for "a human being performs an act of translation, in the full sense of the word, when receiving a speech-message from any other human being," such that "[i]ntimacy . . . can be defined as confident, quasi-immediate translation" (47).

As something that is both intensely personal and fundamentally communal, translation offers a helpful if paradoxical window on larger processes of meaning making across languages and cultures. Readers of published translations define on their own terms texts that require collective efforts-even, and especially, when the efforts of the primary participants, such as Indigenous miners, are not acknowledged. By using mistranslation to understand how Indigenous knowledges shaped new technologies in the Americas, how colonial writers incorporated these knowledges into their own vocabularies, and how the hybrid lexicon of colonial scientific writing 
was replaced by European translators who imparted their own ideas of color and classification, we take advantage of the inherent paradoxes of translation. Instead of bemoaning what is lost in the translation from Quechua to Quechuañol, or celebrating Montagu's, Lange's, Hautin de Villars's, and Lenglet du Fresnoy's works as acts of creative revision, we can convert the lettered record of mistranslation into evidence of Indigenous knowledge production and seventeenth-century racial category making. In doing so, the study of translation becomes a mechanism that reveals the entangled natures of hybrid colonial knowledges and the development of color categories and racial classifications. Accepting translation's many inequivalences, and using them to read around archival silences, become ways to decipher the multilingual registers of the early Americas and to shed new light on the agencies of women and men who shaped the history of the New World and its many ways of knowing.

\section{NOTES}

For their help with this article, I thank Anna Brickhouse, Larissa Brewer-García, Catalina Méndez Vallejo, Ricardo Padrón, Joel Rini, Vanessa Wilkie, Jessica Wolfe, and Nadine Zimmerli.

1. Unless otherwise noted, all translations from the Spanish, Quechuañol, French, and German are my own.

2. Some scholars define Quechuañol as a Quechuan dialect marked by the frequent use of loan words from Spanish (Sichra 115-16; Delgado P. 37-38), while others understand it as a creolized language that developed over time in response to language contact (Luykx 138; Escobar and Potowski 148). Some argue that Quechuañol is an "interlanguage" that emerges from highly literary methods of translation, often by translators working in poetry, philosophy, and sacred script (Wiesse Rebagliati 104). On Andean diglossia, see Cerrón Palomino; Escobar; Lipski; Sánchez.

3. Although these terms were coined in the twentieth century, hybrid languages have long histories in the Americas. Nahuañol literacies have been recorded from the sixteenth century through the present in Mexico (McDonough), and nineteenth-century English speakers who immigrated to California began to write letters in Spanglish soon after their arrival (Train). Hybrid tongues continuously fork over time and in different places, as Anzaldúa explains in her reading of Chicano Spanish (75-86).

4. When the crown recalled Álvaro Alonso Barba from Alto Perú to Spain to improve its mining operations, he suggested that Spain adopt Andean legal frameworks regarding mine discovery. See Barnadas 223-25.

5. In colonial studies, mestizo refers to people of mixed parentage; the term is applied to, claimed, and rejected by people of varying degrees of Indigenous, African, and European ancestry in different places and historical moments (Rappaport 3-20). Criollo refers to people of European heritage who were born in the Americas and thought to suffer the degenerative effects of New World climates. By the late seventeenth century, criollos took pride in their differences from Spaniards and created new aesthetic forms and scientific knowledges. See Bauer and Mazzotti; Katzew; Picón Salas 148-74; Cañizares Esguerra 70-83.

6. The book chapter analyzes cases in Aymara and the amalgamation of mixed metals; other chapters (on gold, copper, and iron) address related questions of Indigenous and Afro-Latin knowledges in vernacular scientific industries in the early Americas.

7. The role of spoken language in colonial translations should not be overlooked. Although González Holguín does not define the verb traducir ("translate"), he offers several cases of movement from one language to another through speech. Many of these expressions include loan words from Spanish, including the name of the language (castellano, la lengua castellana) and colonial administrative positions like that of sheriff (corregidor). See, for instance, his discussion of "el lengua interpreter" ("to interpret language”), explained in colonial Quechua as "runap siminta castilla simi man hurccuni" and "lengua de otro, o interprete" ("the language or interpreter of another"), glossed as "Corregidorpa simi ya chaknin" (561).

8. For a discussion of the gendered nature of these linguistic, technological, and economic changes, see Bigelow, "Women" 356-58. As Andean men shifted to working in amalgamation refineries, women began to refine metals in cylindrical wind ovens made of clay or stone, called huayrachinas (or guairachinas). This pre-Incaic technology is evidence of both change (gendered labor) and continuity (metallurgical traditions) in seventeenth-century Andean communities. On other aspects of continuity and innovation in metalworking and metallurgy, see Esteras Martín; Téreygeol and Castro; Buren and Cohen.

9. The first English editions were printed in London by Samuel Mearne, listed on the title pages as "Bookbinder to the Kings most Excellent Majesty" (Montagu, $A r t)$ and "Stationer to the Kings most Excellent Majesty" (Montagu, First Book); later compilations that bound Barba's book to other mineralogical texts were published by C. Jepson for Oliver Payne (1738) and James Hodges (1740). French editions were printed in Paris by Saugrain 
Pere (1730), Witte et Didot (1733), Pierre-Alexandre Le Prieur (1751), and, in the Hague, by Hondt (1752). German translations were printed in multiple cities, including Gottfried Schultzens Kosten's volumes from Hamburg (1676 and 1739), Gottfried Grosse's in Leipzig (1678), Johann Friedrich Fleischer's editions in Frankfurt (1726 and 1739), and two editions from Vienna, printed by J. P. Krauß (1767) and Peter Conrad Monath (1749), translated from French editions. Johannis Ziegeri's Latin-language edition printed the Arte de los metales along with other works of geology (Nuremberg, 1687). Spanish volumes printed privately include those by "Bernardo Peralta a costa de Francisco Assensio" (1729; "Bernardo Peralta at the cost of Francisco Assensio") and by "la oficina de la viuda de Manuel Fernandez" (1770; "the office of the widow of Manufel Fernández").

10. Barnadas identifies three volumes, in addition to the editions listed in WorldCat, that were published either in German (1676) or in Spanish (Córdoba, 1674; Madrid, 1680). The German volume is confirmed in Ferguson (70). Although no copies of the Córdoba edition remain extant, it was reviewed in the Journal des Sçavants on 11 Feb. 1675 (Barnadas 254-57). Based on its title and structure, the French edition of 1730 seems to be translated from the Córdoba edition of 1674 .

11. Compare the translation of Barba $(10 v-11)$ with those of Montagu (Art 2.44) and Lange (36).

12. See Soto Ruiz for the southern Quechua of Ayacucho, where "puka" ("rojo"; "red;" 126) and "paqu" ("rubio"; "blonde"; 17) overlap in color terms for the sun ("amarillo"; "qillu"; "yellow"; 140), and "bright red" (bermejo in Spanish) is expressed as "pukay-pukay puka" (40). For the eastern Quechua of Bolivia, see Laime Ajacopa et al., whose team lists "puka" as synonymous with "pillku" (74-75).

13. White argues for reading these statements as parody.

14. I thank Jessica Wolfe for help with the paleography and interpretation of this passage. Gladstone's phrase does not align with the conventional Homeric expression

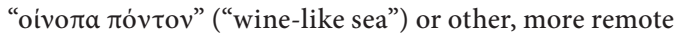
possibilities that Wolfe identifies, such as "Evpooc" ("fair

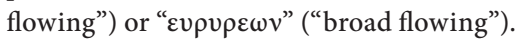

15. I have not been able to confirm who T. W. Brown was. One possibility is the man who received his master of arts from St. John's College, Cambridge, in 1887. In 1895, the examining board of the Royal Colleges of Physicians and Surgeons certified that T. W. Brown passed part 1, in chemistry and physics, and part 4, elementary anatomy, while serving at St. Bartholomew's Hospital. In 1897, he passed his board examination in anatomy and physiology at the same hospital ("Universities and Colleges"). Given the Egyptian focus of the letter, a second, more remote possibility is that Gladstone wrote to Thomas William Brown, an expert in Egyptian agricultural history who directed the Egyptian Ministry of Agriculture's horticultural division in Gizeh (1914-24) and published several papers on ancient and modern Egyptian agriculture, in- cluding a book on the date palm in 1924 and an article called "The Sycamore Fig in Egypt," which explained the Greek roots of the word "sycamore" and its historical connections to fertility and "matrimonial cares" (3). The conclusion was printed on the same page as blurbs about "Miscegenation in Hawaii," "Eugenics as the Basis of Sociology," and a report from the Eugenics Record Office in Cold Spring, New York, which also announced, "Meeting on Saturday Not Open to Public." Although he and Gladstone share interests in Egyptology and scientific inquiry, the dates of this T. W. Brown's activity in Egypt are much later than Gladstone's letters. Brown's correspondence with General Sir Richard Wingate (1861-1953), stationed in India from 1881 to 1883 and in Egypt from 1883 to 1922 , is archived at Durham University (reed.dur.ac.uk/ $\mathrm{xtf} /$ view?docId=ead/sad/wingate. $\mathrm{xml}$ ).

16. See also Berlin and Kay.

17. According to the Real Academia Española's online database (CORDE; corpus.rae.es/cordenet.html), the first recorded use of the phrase lengua general was in Bartolomé de las Casas's description of Cuzco in book 3, chapter 255 of his Historia apologética sumaria ("Summary of the Apologetic History"). Half the references are from books published in Peru or Ecuador; another thirtynine percent are from books published in Spain, often about the Andes. The seventeenth century accounts for the overwhelming majority of cases (nearly seventy percent); citations indexed in the twentieth century are often quotations from early modern sources, such as those found in Alonso's study of language contact in sixteenthcentury Spain and its influence on Spanish speakers in Latin America, whom Alonso calls "los futuros pobladores de América" ("the future settlers of America"; 43).

\section{Works Cited}

Acosta, José de. Historia natural y moral de las Indias. Seville, 1590. Google Books, books.google.com/books ?id=26zAd4TrWXsC.

Alonso, Amado. Estudios lingüísticos: Temas hispanoamericanos. Editorial Gredos, 1967.

Anzaldúa, Gloria. Borderlands / La frontera: The New Mestiza. 3rd ed., Aunt Lute Books, 2007.

Aristotle. Física [Physics]. Edited and translated by Guillermo de Echandía, Editorial Gredos, 1995. La Universidade Estadual de Feria de Santana, www2.uefs .br/filosofia-bv/pdfs/aristoteles_05.pdf.

Barba, Álvaro Alonso. Arte de los metales en que se enseña el veradero beneficio de los de oro, y plata por açogue. Madrid, 1640. Making of the Modern World, www.gale.com/primary-sources/the-making-of-the -modern-world.

Barnadas, Josep María. Alvaro Alonso Barba (1569-1662): Investigaciones sobre su vida y obra. Biblioteca Minera Boliviana, 1986. 
Bassnett, Susan. Translation. Routledge, 2014.

Bauer, Ralph, and José Antonio Mazzotti, editors. Creole Subjects in the Colonial Americas: Empires, Texts, Identities. U of North Carolina P, 2009.

Bentancor, Orlando. "Matter, Form, and the Generation of Metals in Alvaro Alonso Barba's Arte de los metales." Journal of Spanish Cultural Studies, vol. 8, no. 2, 2007, pp. 117-33.

Berlin, Brent, and Paul Kay. Basic Color Terms: Their Universality and Evolution. U of California P, 1969.

Bigelow, Allison Margaret. "La dote natural: Género y el lenguaje de la vida cotidiana en la minería andina." Anuario de estudios bolivianos, vol. 22, no. 2, 2016, pp. 145-68.

- "Women, Men, and the Legal Languages of Mining in the Colonial Andes." Ethnohistory, vol. 63, no. 2, 2016, pp. 351-80.

Bleichmar, Daniela. El imperio visible. Fondo de Cultura Económica, 2016.

Borras, Gérard. “Organología de la tarka en la zona circunlacustre del Titicasa." Diablos tentadores y pinkillus embriagadores... en la fiesta de Anata/Phujllay: Estudios de antropología musical del carnival en los Andes de Bolivia, vol. 1, edited by Arnaud Gérard, Plural Editores, 2010, pp. 41-67.

Brickhouse, Anna. The Unsettlement of America: Translation, Interpretation, and the Story of Don Luis de Velasco, 1560-1945. Oxford UP, 2015.

Brokaw, Galen. "Semiotics, Aesthetics, and the Quechua Concept of Quilca." Colonial Mediascapes: Sensory Worlds of the Early Americas, edited by Matt Cohen and Jeffrey Glover, U of Nebraska P, 2014, pp. 166-203.

Brown, Thomas William. Date Palm in Egypt. Ministry of Agriculture, 1924.

—. "The Sycamore Fig in Egypt." Journal of Heredity, vol. 8, no .1, 1917, pp. 3-12.

Buren, Mary van, and Claire R. Cohen. "Cambios tecnológicos en la producción de plata después de la conquista española en Porco, Bolivia." Boletín del Museo Chileno de Arte Precolombino, vol. 15, no. 2, 2010, pp. 29-46.

Cañizares Esguerra, Jorge. Nature, Empire, and Nation: Explorations of the History of Science in the Iberian World. Stanford UP, 2006.

Cassin, Barbara, et al. Introduction. Dictionary of Untranslatables: A Philosophical Lexicon, edited by Cassin et al., Princeton UP, 2014, pp. xvii-xx.

“Caxon, N. 2." Oxford English Dictionary, 2018, www.oed .com/view/Entry/29320.

Cerrón Palomino, Rodolfo. "El contacto inicial quechuacastellano: La conquista del Perú con dos palabras." Lexis, vol. 34, no. 2, 2010, pp. 369-81. Pontifical Catholic University of Peru, revistas.pucp.edu.pe/index .php/lexis/article/view/1545.
Chacón Torres, Mario. Arte virreinal en Potosí: Fuentes para su historia. Escuela de Estudios Hispanoamericanos, 1973.

Coldiron, Anne. Printers without Borders: Translation and Textuality in the Renaissance. Cambridge UP, 2015.

Colón, Cristóbal. Los cuatro viajes. Edited by Consuelo Varela, Alianza Editorial, 2011.

Cope, Douglas R. The Limits of Racial Domination: Plebeian Society in Colonial Mexico City, 1660-1720. U of Wisconsin P, 1994.

Darwin, Charles. The Descent of Man, and Selection in Relation to Sex. London, 1871. 2 vols.

- On the Origin of Species by Means of Natural Selection; or, The Preservation of Favoured Races in the Struggle for Life. London, 1859.

Davidson, Jenny. Breeding: A Partial History of the Eighteenth Century. Columbia UP, 2009.

Delgado P., Guillermo. "Una aproximación filológica para entender las luchas por la autonomía Ayllica: El concepto quechua del poder." Conocimiento indígena y globalización, edited by Ethel Wara Alderete, Editorial Abya Yala, 2005, pp. 35-58.

Escobar, Anna María. "Spanish in Contact with Quechua." The Handbook of Hispanic Sociolinguistics, edited by Manuel Díaz Campos, Wiley-Blackwell, 2011, pp. 323-51.

Escobar, Anna María, and Kim Potowski. El español de Estados Unidos. Cambridge UP, 2015. Google Books, books.google.com/books?id=3JxrCgAAQBAJ

Esteras Martín, Cristina. "Acculturation and Innovation in Peruvian Viceregal Silverwork." The Colonial Andes: Tapestries and Silverwork, 1530-1830, edited by Elena Phipps et al., Yale UP, 2004, pp. 58-71.

Ferguson, John. Bibliotheca Chemica, a Catalogue of the Alchemical, Chemical and Pharmaceutical Books in the Collection of the Late James Young of Kelly and Durris. J. Maclehose and Sons, 1906. Google Books, books.google.com/books?id=zqyNHmOksDwC.

Garcilaso de la Vega, El Inca. Comentarios Reales de los Inca. 1609. Edited by Carlos Araníbar, vol. 1, Fondo de Cultura Económica, 2004

Geiger, Lazarus. Zur Entwicklungsgeschichte der Menschheit. 1871. Salzwasser Verlag, 2012. Google Books, books.google.com/books?id=-SL-N7fBMQQC .

Gladstone, William. Letter to T. W. Brown. 30 Dec. 1886 William Ewart Gladstone Collection, MS GLA 180 Huntington Library, Los Angeles.

. Letter to an unnamed recipient. Circa 1885. William Ewart Gladstone Collection, MS GLA 618, Huntington Library, Los Angeles.

González Holguín, Diego. Vocabulario de la lengua general de todo el Peru llamada lengua Qquichua o del Inca. 1608. Universidad Nacional Mayor de San Marcos, 1989 
Gründlicher Unterricht von den Metallen, darinnen beschrieben wird, wie sie werden in der Erden generirt... im Jahr 1664: Hernach in das Engländische übersetzt durch Edward, Graff von Dandwich. Anno 1669. Ephrata, 1763. Early American Imprints, Series I: Evans, 16391800, no. 9333, docs.newsbank.com/s/Evans/eaidoc/ EAIX/0F3015DB8F5B36A0/0D0CB581AB6F1535.

Hammonds, Evelynn, and Rebecca M. Herzig. The $\mathrm{Na}$ ture of Difference: Sciences of Race in the United States from Jefferson to Genomics. MIT Press, 2008.

Hautin de Villars, Charles, translator. Traité de l'art métalique: Extrait des oeuvres d'Alvare-Alfonse Barba, célebre artiste dans les mines du Potozi. By Álvaro Alonso Barba, Chez Saugrain, 1730. Making of the Modern World, www.gale.com/primary-sources/the -making-of-the-modern-world.

Kant, Immanuel. Observations on the Feeling of the Beautiful and Sublime. Observations on the Feeling of the Beautiful and Sublime and Other Writings, edited by Patrick Frierson and Paul Guyer, Cambridge UP, 2012, pp. 11-64.

Katzew, Ilona. Casta Painting: Images of Race in Eighteenth-Century Mexico. Yale UP, 2004.

Kotelmann, Ludwig. "Die Augen von 9 Lappländern, 3 Patagoniern, 13 Nubiern und 1 Neger vom weissen Nil.” Waldenburg, pp. 701-03.

Laime Ajacopa, Teofilo, et al. Diccionario bilingüe: Iskay simipi yuyak'ancha (Quechua-Castellano/CastellanoQuechua). 2nd ed., Centro Cultural JAYMA, 2007. Universidad de Cochabamba, atlas.umss.edu.bo:8080/ xmlui/handle/123456789/384.

Lange, Johann, translator. Albaro Alonso Barba BergBüchlein: Darinnen von der Metallen und Mineralien Generalia und Ursprung. By Álvaro Alonso Barba, Hamburg, 1676.

Lenglet du Fresnoy, Nicolas. Métallurgie ou l'art de tirer et de purifier les métaux. Vol. 1, Chez Didot, 1751. HathiTrust, babel.hathitrust.org/cgi/pt?id=ucm .5327731029 .

Lewis, Laura. Hall of Mirrors: Power, Witchcraft, and Caste in Colonial Mexico. Duke UP, 2003.

Lipski, John. "On the Tenacity of Andean Spanish: Intracommunity Recycling." Spanish Language and Sociolinguistic Analysis, edited by Sandro Sessarego and Fernando Tejedo-Herrero, John Benjamins Publishing Company, 2016, pp. 109-34.

Llanos, García de. Diccionario y maneras de hablar que se usan en las minas y sus labores en los ingenios y beneficios de los metales. 1609. Edited by Gunnar Mendoza L. and Thierry Saignes, MUSEF Editores, 1983.

Luykx, Aurolyn. "Paradoxes of Quechua Language Revitalization in Bolivia: Back and Forth along the Language Continuum." Handbook of Language and Ethnic Identity: The Success-Failure Continuum in Language and Ethnic Identity Efforts, vol. 2, edited by
Joshua Fishman and Ofelia Garcia, Oxford UP, 2011, pp. 137-50. Google Books, books.google.com/books ?id=OBoSDAAAQBAJ.

Magnus, Hugh. "A Research Study of Primitive Peoples' Awareness and Perception of Colour." The Debate about Colour Naming in Nineteenth-Century German Philology: Selected Translations, edited by Barbara Saunders, Leuven UP, 2007, pp. 133-82.

Martínez, María Elena. Genealogical Fictions: Limpieza de sangre, Religion, and Gender in Colonial Mexico. Stanford UP, 2008.

McDonough, Kelly. The Learned Ones: Nahua Intellectuals in Postconquest Mexico. U of Arizona P, 2014.

Mignolo, Walter. The Darker Side of the Renaissance: Literacy, Territoriality, Colonization. 2nd ed., U of Michigan P, 2003.

Minshew, John. НГЕM $\Omega$ N TA $\Sigma \Gamma \Lambda \Omega \Sigma \Sigma \mathrm{A} \Sigma$, Id Est, Ductor in Linguas, The Guide into Tongues ... the Reasons and Deriuations of All or the Most Part of Wordes, in These Eleuen Languages. London, 1617. Nuevo Tesoro Lexicográfico de la Lengua Española, ntlle.rae.es/ ntlle/SrvltGUILoginNtlle.

Molina Martínez, Miguel. "Legislación minera colonial en tiempos de Felipe II.” XIII Coloquio de historia canario-americana-VIII Congreso internacional de historia de América de la Asociación española de americanistas, edited by Francisco Morales Padrón, Cabildo Insular de Gran Canaria, 2000, pp. 1014-29.

Money, Mary. Oro y plata en los Andes: Significado en los diccionarios de Aymara y Quechua, siglo XVI-XVII. CIMA, 2004

Montagu, Edward, translator. The Art of Metals, in Which Is Declared the Manner of Their Generation and the Concomitants of Them: In Two Books. By Álvaro Alonso Barba, 2nd ed., London, 1674. Early English Books Online, gateway.proquest.com/openurl?ctx ver $=Z 39.88-2003 \&$ res_id=xri:eebo\&rft_id=xri:eebo :citation:12010974.

-, translator. The First Book of the Art of Metals, in Which It Is Declared the Manner of Their Generation and the Concomitants of Them. By Álvaro Alonso Barba, London, 1670. Early Modern Books Online, gateway.proquest.com/openurl?ctx_ver=Z39.88-2003 \&res_id=xri:eebo\&rft_id=xri:eebo:citation:11156797.

"Mulatto, N. and Adj." Oxford English Dictionary, 2018, www.oed.com/view/Entry/123402.

Nebrija, Antonio de. Gramática de la lengua castellana. 1492. Edited by Antonio Quilis, Editora Nacional, 1981.

Oudin, César. Tesoro de las dos lenguas francesa y española / Thresor des deux langues françoise et espagnolle. Paris, 1607. Nuevo Tesoro Lexicográfico de la Lengua Española, ntlle.rae.es/ntlle/SrvltGUILoginNtlle.

Picón Salas, Mariano. De la conquista a la independencia. Fondo de Cultura Económica, 1944. 
Plato. Timaeus. Timaeus and Critias, translated by Desmond Lee, revised translation by T. K. Johansen, Penguin Books, 2008, pp. 1-91.

Poma de Ayala, Felipe Guaman. Nueva corónica y buen gobierno. 2nd ed., edited by Franklin Pease G. Y., vol. 1, Fondo de Cultura Económica, 2005.

Portuondo, María. Secret Science: Spanish Cosmography and the New World. U of Chicago P, 2009.

Quispe-Agnoli, Rocío. "Cuando Occidente y los Andes se encuentran: Qellqay, escritura alfabética, y tokhapu en el siglo XVI." Colonial Latin American Review, vol. 14, no. 2, 2005, pp. 263-98.

Rappaport, Joanne. The Disappearing Mestizo: Configuring Difference in the Colonial Kingdom of Granada. Duke UP, 2014.

Rappaport, Joanne, and Tom Cummins. Beyond the Lettered City: Indigenous Literacies in the Andes. Duke UP, 2012.

Restall, Matthew. The Black Middle: Africans, Mayas, and Spaniards in Colonial Yucatan. Stanford UP, 2009.

Ricoeur, Paul. On Translation. Translated by Eileen Brennan, Routledge, 2006.

Sánchez, Liliana. Quechua-Spanish Bilingualism: Interference and Convergence in Functional Categories. John Benjamins Publishing Company, 2003. ProQuest Ebook Central, ebookcentral.proquest.com/ lib/uva/detail.action?docID $=623025$

Sánchez Gómez, Julio, et al. La savia del imperio: Tres estudios de economía colonial. Universidad de Salamanca, 1997.

Santo Tomás, Domingo de. Lexicon o vocabulario de la lengua general del Perv co $[\mathrm{m}]$ puesto por el Maestro F. Domingo de S. Tomás de la orden de S. Domingo. Valladolid, 1560. HathiTrust, babel.hathitrust.org/cgi/pt ?id=ucm. 5323537564 .

Saunders, Barbara. Introduction. The Debate about Colour Naming in Nineteenth-Century German Philology: Selected Translations, edited by Saunders, Leuven UP, 2007, pp. 7-41.

Schroeder, Carl. "Die Entwicklung des Farbensinnes am menschlichen Auge." Waldenburg, pp. 545-46, 561-64.

Shapin, Steven. Never Pure: Historical Studies of Science As If It Was Produced by People with Bodies, Situated in Time, Space, Culture, and Society, and Struggling for Credibility and Authority. Johns Hopkins UP, 2010.

Sichra, Inge. La vitalidad del quechua: Lengua y sociedad en dos provincias de Cochabamba. Plural Editores, 2003. Google Books, books.google.com/books?id= epf1KrUl2XsC.
Smith, Pamela H. "Vermilion, Mercury, Blood, and Lizards: Matter and Meaning in Metalworking." Materials and Expertise in Early Modern Europe: Between Market and Laboratory, edited by Ursula Klein and Emma C. Sparry, U of Chicago P, 2009, pp. 29-49.

Soto Ruiz, Clodoalto. Runasimi-Kastillanu-Inlis Llamkaymanaq Qullqa: Ayacucho-Chanka I rakta / Quechua-Spanish-English Functional Dictionary: Ayacucho-Chanka. Vol. 1, Lluvia Editores, 2012. University of Illinois Center for Latin American and Caribbean Studies, www.clacs.illinois.edu/quechua/ default.aspx.

Steiner, George. After Babel: Aspects of Language and Translation. 3rd ed., Oxford UP, 1998.

Téreygeol, Florian, and Celia Castro. "La metalurgia prehispánica de la plata en Potosí." Mina y metalurgia en los Andes del Sur: Desde la época prehispánica hasta el siglo XVII, edited by Pablo José Cruz and JeanJoinville Vacher, Instituto Francés de Estudios Andinos, 2008, pp. 11-28.

Train, Robert W. "Becoming Bilingual, Becoming Ourselves: Archival Memories of Spanglish in Early Californian Epistolary Texts." Hispania, vol. 96, no. 3, 2013, pp. 438-39. Project Muse, muse.jhu.edu/article/ $521637 /$ pdf.

"Universities and Colleges." The British Medical Journal, vol. 1, no. 1791, 1895, pp. 957-59. JSTOR, www.jstor .org/stable/20216002.

Vetter Parodi, María Luisa. Plateros indígenas en el Virreinato del Perú, siglos XVI y XVII. Fondo Editorial UNMSM, 2008.

Waldenburg, L., editor. Berliner klinische Wochenschrift. August Hirschwald, 1879. Google Books, books.google .com/books?id=r031AAAAMAAJ.

Washington, Lawrence, et al. The Final Sale of the Relics of General Washington. Thomas Birch's Sons, 1891. Google Books, books.google.com/books?id=hB8FAAAAYAAJ.

White, Gabrielle D. V. "Should We Take Kant Literally? On Alleged Racism in Observations on the Feeling of the Beautiful and Sublime." Philosophy and Literature, vol. 37, no. 2, 2013, pp. 542-53.

Wiesse Rebagliati, Jorge. "Babel revisitada." Apuntes, no. 38, 1996, pp. 89-111. Universidad de Pacifico, revistas.up.edu.pe/index.php/apuntes/article/view/717.

Wyke, Ben van. "Imitating Bodies and Clothes: Refashioning the Western Conception of Translation." Thinking through Translation with Metaphors, edited by James St. André, St. Jerome Publishing, 2010, pp. 17-46.

Young, Robert J. C. “That Which Is Casually Called a Language." PMLA, vol. 131, no. 5, Oct. 2016, pp. 1207-21. 